\title{
A Lignocellulosic Ethanol Strategy via Nonenzymatic Sugar Production: Process Synthesis and Analysis
}

\author{
Jeehoon Han ${ }^{1}$ Jeremy S. Luterbacher, David Martin Alonso, \\ James A. Dumesic and Christos T. Maravelias* \\ Department of Chemical and Biological Engineering \\ University of Wisconsin-Madison \\ Madison, WI 53706, USA
}

\begin{abstract}
The work develops a strategy for the production of ethanol from lignocellulosic biomass. In this strategy, the cellulose and hemicellulose fractions are simultaneously converted to sugars using a $\gamma$-valerolactone (GVL) solvent containing a dilute acid catalyst. To effectively recover GVL for reuse as solvent and biomass-derived lignin for heat and power generation, separation subsystems, including a novel $\mathrm{CO}_{2}$-based extraction for the separation of sugars from GVL, lignin and humins have been designed. The sugars are cofermented by yeast to produce ethanol. Furthermore, heat integration to reduce utility requirements is performed. It is shown that this strategy leads to high ethanol yields and the total energy requirements could be satisfied by burning the lignin. The integrated strategy using corn stover feedstock leads to a minimum selling price of \$5 per gallon of gasoline equivalent, which suggests that it is a promising alternative to current biofuels production approaches.
\end{abstract}

Keywords: Biofuels; $\gamma$-valerolactone ; process design; heat integration; technoeconomic evaluation.

\footnotetext{
${ }^{1}$ Current address: School of Chemical Engineering, Chonbuk National University, Jeonju 561-756, Korea.

* Corresponding author: Tel.: +1 608265 9026; fax: +1 608262 5435. E-mail address: christos@engr.wisc.edu

†Electronic supplementary content (ESC) available.
} 


\section{Introduction}

The United States used about 13 billion gallons of renewable fuels in 2010, and this number is predicted to rise to 36 billion gallons by 2022 (Schnepf and Yacobucci, 2010).

Lignocellulosic biomass can be a potential sustainable source for biofuel production to meet future renewable fuel demands (Daoutidis et al., 2013; Demirbas, 2007). Biofuels, such as bioethanol, biobutanol, and biogasoline, can be produced from lignocellulosic biomass via three different process platforms: (1) biochemical, using enzymatic or chemical hydrolysis, followed by microbial fermentation (Anex et al., 2010; Conde-Mejía et al., 2013; Gnansounou and Dauriat, 2010; Kazi et al., 2010; Uppugundla et al., 2014; Zhong et al., 2009) (2) thermochemical, using gasification/pyrolysis and subsequent catalytic upgrading or carbohydrate reforming (Anex et al., 2010; Corma et al., 2011; Huber et al., 2006; Lange, 2007; Pham et al., 2014; Swanson et al., 2010; Wright et al., 2010); and (3) catalytic, using chemical hydrolysis and dehydration, followed by catalytic upgrading of platform chemicals (Alonso et al., 2010; Bond et al., 2014; Braden et al., 2011; Huber et al., 2006; Lange, 2007; Sen et al., 2012). Among the various competing biofuel technologies, biochemical ethanol production from lignocellulosic biomass has received the most attention in the literature (Humbird et al., 2011; Kazi et al., 2010). Several studies have focused on the synthesis and technoeconomic evaluation of biorefineries based on the aforementioned platforms (Dale and Ong, 2014; Floudas et al., 2012; Martín and Grossmann, 2011; Pham and El-Halwagi, 2012; Sammons Jr et al., 2008; Tao et al., 2011; Wright and Brown, 2007). 
Cellulose and hemicellulose components of the lignocellulosic biomass are hydrolyzed to 5-carbon $\left(\mathrm{C}_{5}\right)$ and 6-carbon $\left(\mathrm{C}_{6}\right)$ sugars either by acids (Luterbacher et al., 2014) or enzymes (Kazi et al., 2010). The sugars are then co-fermented or fermented separately either by yeast (Kádár et al., 2007) or bacteria (Olsson and Hahn-Hägerdal, 1996) to produce ethanol. The biomass residues (primarily lignin) are generally used for producing process heat and electricity (Holladay et al., 2007; Kazi et al., 2010). Chemical (acid) hydrolysis may offer economic advantages because of the absence of expensive enzymes (15-20\% of the total ethanol production cost) (Humbird et al., 2011; Kazi et al., 2010). However, there are two key challenges: (1) production of sugar degradation products (e.g., furfural, levulinic acid and humins) that leads to low sugar yields; and (2) high capital cost of reaction systems resulting from low sugar concentration (Lee et al., 1999).

Recently, Luterbacher et al. (Luterbacher et al., 2014) developed a novel chemical hydrolysis process for sugar production at high yields using $\gamma$-valerolactone (GVL) and water as a solvent containing dilute sulfuric acids (SA) as a catalyst. They reported that the sugars could be recovered and effectively concentrated by extraction using liquid $\mathrm{CO}_{2}$ from the GVL/water solution. Subsequently, the concentrated sugars can be upgraded to ethanol at high yields by co-fermentation using engineered yeast strains (Lau and Dale, 2009). The process can potentially produce sugars more economically than other methods because it does not utilize expensive enzymes (cellulases). Furthermore, GVL is a biomass-derived renewable solvent which is more affordable than currently used enzymes. Finally, this technology offers great flexibility because it leads to sugar intermediates which are compatible with biological or chemical upgrading strategies to a range of higher value materials (e.g., fuels, fuels additives, and chemicals). 
However, potential bottlenecks for the further development and commercialization of process based on this technology are (1) the downstream separations necessary to recover sugars (to be fermented to ethanol) from GVL, lignin and humins and (2) the separation of GVL (to be recycled) from lignin and humins (to be used for heat and power generation). Accordingly, in this paper separation subsystems are developed to carry out the aforementioned separations. The nonenzymatic hydrolysis and separation subsystems have been integrated into a process, to perform a technoeconomic analysis. The ultimate goal is to identify the major cost and technological drivers, thereby leading future research efforts in fundamental research in the area of catalysis and separations.

\section{Materials and Methods}

\subsection{Process Description}

The strategy reported herein combines two conversion subsystems for the (1) chemical hydrolysis of hemicellulose and cellulose to soluble sugars and (2) fermentative upgrading of sugars to ethanol as well as separation subsystems for (1) the separation of sugars (to be fermented to ethanol) from GVL, lignin and humins and (2) the separation of GVL (to be recycled) from lignin and humins (to be used for heat and power generation).

\subsubsection{Nonenzymatic sugar production}

Luterbacher et al. (2014) proposed a two-stage dilute acid reaction system (Fig. 1) for the chemical hydrolysis of hemicellulose and cellulose to $\mathrm{C}_{5}$ and $\mathrm{C}_{6}$ sugars. In a two-stage dilute acid reaction system. Corn stover is first treated in GVL-water ( $4: 1$ mass ratio) solvent containing 0.15 M SA for 1 hour at relatively mild conditions (390 K) with a 
solvent to biomass mass ratio of 4 (R-1 in Fig 1 ). In the first reaction stage, hemicellulose is converted to $\mathrm{C}_{5}$ sugars and furfural at $64.2 \%$ and $14.5 \%$ molar yields, respectively (reactions 1 and 2 in Table 1), whereas cellulose is converted to $\mathrm{C}_{6}$ sugars, levulinic acid (LA) and 5-hydroxymethylfurfural (HMF) at 10.3\%, $0.9 \%$ and $0.6 \%$ molar yields, respectively (reactions 3,4 and 5 in Table 1 ). Most of the $\mathrm{C}_{5}$ sugars and lignin are solubilized in the first reaction stage, and the resulting mixture is filtered to separate solid and liquid fractions (S-1). The insoluble materials (containing cellulose and remaining hemicellulose) separated from the liquid mixture (containing xylose, furfural, lignin and GVL/water) are sent to the second reaction stage (stream 4). The liquid mixture (stream 5) is sent to a holding tank (V-1) where it is mixed with the hydrolyzed slurry (stream 6) leaving the second reaction stage prior to being sent to a subsequent separation subsystem for recovering sugars.

The remaining solids (primarily cellulose and some hemicellulose) are then again treated in GVL-water ( $4: 1 \mathrm{wt} \%$ ) solution containing $5 \mathrm{mM}$ SA for 0.5 hour at higher temperatures (430-490K) with a solvent to biomass mass ratio of 20 (R-2 in Fig 1). The second stage is designed as a vertical continuous countercurrent reactor, in which the liquid flows through the solids, which are advancing in the opposite direction. Therefore, soluble sugars are produced along with the progressive heating of the solids. The hot liquid (490K) is driven down the reactor and it cools to $430 \mathrm{~K}$, while the cold solids are progressively heated from 430 to $490 \mathrm{~K}$ with the solids moving upward. In the second reaction stage, cellulose is converted to $\mathrm{C}_{6}$ sugars, LA and HMF at $66.5 \%, 11.2 \%$ and $5.4 \%$ molar yields, respectively, whereas hemicellulose is converted to $\mathrm{C}_{5}$ sugars and furfural at $27.3 \%$ and $72.7 \%$ molar yields, respectively. Based on the liquid collected from both the first and second reactors, 
soluble $\mathrm{C}_{5}$ and $\mathrm{C}_{6}$ sugars are produced at $70 \%$ and $69 \%$ molar yields, respectively (reactions 1 and 3 in Table 1). Soluble degradation products, such as furfural, LA, HMF and humins, are also formed at 30\%, 10.8\%, 5.4\% and 14.8\% molar yields, respectively (reactions 2, 4, 5 and 6 in Table 1).

\subsubsection{Separation subsystems}

In order to separate the sugars from GVL, Luterbacher et al. (2014) proposed a separation system wherein the aqueous phase containing the sugars was rendered immiscible with GVL by addition of liquid $\mathrm{CO}_{2}$ at 68 bar and $296 \mathrm{~K}$. This phase separation leads to an increase in total soluble sugar concentration of up to $12.5 \mathrm{wt} \%$ and a decrease in GVL concentration down to $1.3 \mathrm{wt} \%$ as about $90 \%$ of the sugars remain in the aqueous (water) phase, while most of the GVL, lignin and sugar degradation products partition into the organic $\left(\mathrm{CO}_{2}\right)$ phase. Following this separation, $\mathrm{CO}_{2}$ (to be reused in the extraction) has to be separated from GVL and biomass residues (lignin and humins). To accurately model a vapor-liquid equilibrium (VLE) unit operation for this task, the Peng-Robinson equation of state (EoS) was modified based on VLE experiments performed in the lab. For the separation of GVL (to be recycled to the biomass deconstruction system) from biomass residues (to be used for heat and power generation), an evaporation step was used following the suggestion of Han et al. (2014).

\subsubsection{Fermentative ethanol production}

To achieve microbial fermentation to ethanol, SA needs to be neutralized and GVL concentrations reduced, because they can inhibit microbial growth (Luterbacher et al., 2014). Once this has been achieved, the soluble $C_{5}$ and $C_{6}$ sugars can be upgraded 
biologically to $5 \mathrm{wt} \%$ of ethanol with $87 \%$ molar yields on engineered yeast strains at 303 K for 6 days of fermentation (reactions 7 and 8 in Table 2) (Lau and Dale, 2009;

Luterbacher et al., 2014). Note that the nonenzymatic sugar production step can be integrated with other conversion technologies that lead to different fuels, fuel additives, or

chemicals. However, we choose to integrate with a sugars-to-ethanol process in order to draw comparisons with the "benchmark" NREL lignocellulosic ethanol process used widely in the literature.

\subsection{Design basis and assumptions}

Based on the experimental data and simulation results, the cost for the units in four sections (extraction, $\mathrm{CO}_{2}$ separation, GVL production, and biomass residues separation) was estimated using Aspen Process Economic Analyzer. The equipment cost of the remaining sections was estimated using an exponential scaling expression based on the equipment size and cost data in the NREL's design (Humbird et al., 2011; Kazi et al., 2010). The equipment and utility costs of the heat exchangers network were also calculated using Aspen Energy Analyzer. To compare the strategy reported herein with previous technoeconomic analyses of lignocellulosic biofuel production, enzymatic/biochemical ethanol production (Kazi et al., 2010) and catalytic alkenes production (Han et al., 2014), the same feedstock and processing rate (2000 dry tons of corn stover per day) were selected. The total ethanol production is $50.6 \times 10^{6} \mathrm{gal}$ of ethanol $\mathrm{yr}^{-1}$. All the equipment cost is indexed to year 2007, using the Chemical Engineering Plant Cost Index (Lozowski, 2012) . 


\section{Results and Discussion}

\subsection{Process Synthesis}

Based on the technologies outlined in the previous section, a process for producing a liquid biofuel (ethanol) from lignocellulosic biomass was synthesized. Fig. 2 shows the proposed process which consists of ten main sections: (1) biomass handling, (2) two-stage reaction, (3) extraction, (4) $\mathrm{CO}_{2}$ separation, (5) GVL production, (6) GVL recovery, (7) fermentation, (8) ethanol purification, (9) wastewater treatment, and (10) heat and power generation. After physical size reduction (Kazi et al., 2010) and chemical hydrolysis of lignocellulosic biomass (stream 7), GVL removal from the liquid hydrolyzed mixture using liquid $\mathrm{CO}_{2}$ takes place at $296 \mathrm{~K}$ and 68 bar with a $\mathrm{CO}_{2}$ to feed mass ratio of 0.46 . After 5 extraction stages (E-1 in Fig 2), 99.6\% of GVL, 99.4\% of furfural, 95.1\% of LA and 52.0\% of HMF are recovered in the $\mathrm{CO}_{2}$-expanded GVL phase with the liquid $\mathrm{CO}_{2}$ (stream 10), whereas $85.5 \%$ of sugars remain in the SA-containing aqueous phase, which is sent to the fermentation section (stream 8).

Carbon dioxide and GVL have to be separated so that GVL can be reused in the reaction (biomass hydrolysis) and $\mathrm{CO}_{2}$ can be reused in the extraction. To achieve these tasks, the GVL-rich mixture (stream 10) is first sent to a $\mathrm{CO}_{2}$ separation system consisting of five vapor-liquid separators (S-2 S-6) connected in series which undergo an increase in temperature (S-2 in Fig 2) and reduction in pressure (S-3 S-6) leading to $\mathrm{CO}_{2}$ vapor streams. $99 \%$ of $\mathrm{CO}_{2}$ is separated from the GVL-rich stream and recompressed $(\mathrm{C}-1 \sim \mathrm{C}-4)$ before is sent to the extraction section. Following the $\mathrm{CO}_{2}$ separation, 33\% of the GVL-rich stream (stream 17) is diverted to be vaporized in a gas-solid separator (S-7) for separating 
and cleaning the GVL from soluble biomass residues (lignin and humins). To make up the loss of GVL, a further 33\% of the GVL-rich stream (stream 18) is sent back to the reaction section only after going through a catalytic stage where LA is upgraded to GVL using $\mathrm{H}_{2}$ from FA decomposition over RuSn 4 /C catalysts (R-3). The remaining GVL-rich stream (stream 19), containing also lignin and humins, is recycled directly to the two-stage reaction section to reduce the heat load for the evaporation of GVL.

Following the evaporation of GVL (S-7), most of the GVL remaining in the biomass residues is recovered by a liquid-solid separator with addition of water (S-8) followed by a distillation step to recycle the water (D-1) (stream 24), whereas the biomass residues and non-recovered GVL are burned to produce process heat and electricity in the boiler/turbogenerator (stream 25).

Prior to ethanol production, the aqueous stream containing sugars, small amounts of GVL, and SA (stream 8) from the extractor (E-1) is neutralized using $\mathrm{Ca}(\mathrm{OH})_{2}$, and the precipitate (gypsum) is removed by filtration (S-9), which is assumed to remove $99.5 \%$ of the precipitated gypsum and the solids are assumed to contain $20 \%$ liquid, as described in the NREL report(Kazi et al., 2010). Sugars present in the neutralized stream are diluted with a water to feed mass ratio of 0.2 and then converted to $5 \mathrm{wt} \%$ of ethanol over engineered yeast strains in a fermenter (R-4) at a molar yield of 87\% (stream 32). After ethanol- $\mathrm{H}_{2} \mathrm{O}$ distillation, $92.5 \mathrm{wt} \%$ of ethanol is obtained at the top of the distillation column (D-2) at $366 \mathrm{~K}$ and 2 bar (stream 33) and is further dehydrated to $99.5 \mathrm{wt} \%$ by vapor-phase molecular sieve adsorption (S-10, stream 35). 47.5\% of the water and GVL separated from the distillation bottoms liquid (stream 34) is recycled to the two-stage reaction section and the remaining fraction is sent to the waste water treatment section.. 


\subsection{Heat Integration and Energy Efficiency}

A potential drawback of the proposed strategy is the large energy requirement for (1) the recompression of $\mathrm{CO}_{2}$ to critical pressure $\left(\mathrm{CO}_{2}\right.$ separation section) and (2) GVL evaporation (GVL recovery section). These duties are high because of the large solvent:biomass ratio (14:1) in the two-stage reaction system and the large $\mathrm{CO}_{2}$ requirement for the separation of sugars (GVL-rich solution: $\mathrm{CO}_{2}$ mass ratio $=2: 1$ ). In particular, when 2000 tons of corn stover are processed per day (358 MW of energy content) the total heating requirement is $242 \mathrm{MW}$, while the electricity requirement is estimated to be 14 MW. Since the energy content of biomass residues is estimated to be $165 \mathrm{MW}$, the total heating and electricity requirements could not have been satisfied by burning the solids alone.

To address this challenge, heat integration including integration between process streams and unit operations was performed. The heat exchanger network (HEN) requires 31 heat exchangers and results in significant energy recovery (168 MW), thereby reducing the heating (cooling) requirements of the process to 74.4 MW (27.2 MW) as shown in Fig. 4. The electricity requirement of the process is estimated to be $14 \mathrm{MW}$. This means that the total heating and electricity requirements ( $88 \mathrm{MW}$ ) could be satisfied by burning the biomass residues, assuming that the efficiencies of heat and electricity generation are $71 \%$ and 30\%, respectively (Kazi et al., 2010). Also, 4.1 MW of net surplus electricity could be sold to the grid. The heat exchanger for transferring heat from the feed stream of the extraction section to the product stream has the largest heat load (32.4 MW).

Fig. 4 shows an energy flow diagram which represents how 100 units (358MW) of energy input (biomass energy content) are converted into various energy outputs (liquid fuels and 
electricity) after heat integration. The energy efficiency, which is the ratio of the energy output to the energy input, for the conversion of the biomass energy content into fuels and electricity is estimated to be $42.4 \%$. The energy (heat and electricity) required to run the process is 24.7 units (88.3 MW). As expected, the most energy intensive section is biomass residue separation by GVL evaporation (44.4 MW, 12.4 units).

\subsection{Capital and operating costs}

The capital costs of all process sections are shown in Table 3. In addition, the capital requirements of the enzymatic production of ethanol, reported by NREL (Kazi et al., 2010), and the catalytic production of alkene oligomers, reported by Han et al. (2014), are included for comparison. The total installed equipment cost is estimated to be $\$ 225.8$ million for the nonenzymatic ethanol production, whereas the total project investment, which includes other direct (e.g., warehouse and site development) and indirect (e.g., engineering, supervision, construction expenses, and contingency) costs, is \$517.2 million. The total installed equipment cost for the nonenzymatic ethanol production is $32.4 \%$ higher than that of the catalytic production of alkene oligomers ( $\$ 170.5$ million) mainly because the catalytic conversion strategy does not use as much solvent due to the absence of a flowthrough reaction and does not require extraction/ $\mathrm{CO}_{2}$ separation steps for sugar production and recovery (\$91.9 million of difference), although the cost of biochemical conversions (\$7.2 million) is lower than that of catalytic conversions (\$29.8 million). The cost of biochemical conversions for the strategy reported herein is lower (by $\$ 14.6$ million) due to smaller fermentation reactors resulting from lower ethanol production, compared to that of the NREL process. However, the total installed equipment cost for our strategy is higher (\$61.7 million) than that of the NREL because the non-enzymatic strategy (1) has a larger 
reaction system (\$49.5 million of difference) resulting from lower overall solids loading (7 wt\%), compared to that of the NREL process (30 wt\%); and (2) requires a $\mathrm{CO}_{2}$-based extraction and a $\mathrm{CO}_{2}$ separation section (\$42.8 million of difference).

The total operating cost is estimated to be $\$ 83.9$ million $\mathrm{yr}^{-1}$. Feedstock cost is the most significant component not only in the non-enzymatic strategy (69\% of the total operating cost), but also in the other strategies, as shown in Table 3. The fixed operating cost (e.g. labor, overhead, insurance and maintenance costs) for the non-enzymatic strategy is $\$ 12.1$ million $\mathrm{yr}^{-1}$, which is slightly higher than the other strategies because it is calculated based on the total installed equipment cost. However, the total operating cost for the nonenzymatic strategy is significantly (35.3\%) lower than that of the NREL process (\$129.7 million $\mathrm{yr}^{-1}$ ) because material costs (sulfuric acid and $\mathrm{CO}_{2}$ costs, $\$ 3.1$ million $\mathrm{yr}^{-1}$ ) are lower than those of the NREL process (sulfuric acid and enzyme costs, \$39.5 million $\mathrm{yr}^{-1}$ ). The total operating cost for the non-enzymatic strategy, on the other hand, is slightly (7.9\%) higher than that of the catalytic production of alkene oligomers due to higher fixed operating costs and material costs including other raw materials (e.g.lime, boiler chemicals, wastewater chemicals) resulting from the fact that the catalytic conversion strategy has no sugar production/recovery steps and higher overall solids loading (16wt\%) in biomass deconstruction reactor (Han et al., 2014).

\subsection{Minimum selling price}

The minimum selling price (MSP) of ethanol (i.e., the price that leads to zero net present value) was calculated (see Table 4) based on the capital and operating costs using the economic parameters, assumptions and discounted cash flow methodology used by NREL (Kazi et al., 2010). Although the average total annualized cost of the non-enzymatic ethanol 
production process ( $\$ 169$ million $\mathrm{yr}^{-1}$ ) is $18.3 \%$ higher than that of the catalytic alkenes production process ( $\$ 143$ million $\mathrm{yr}^{-1}$ ), the MSP of ethanol for the non-enzymatic strategy (\$4.99/gal of gasoline equivalent (GGE)) is 44\$ per GGE lower than the catalytic alkenes production process ( $\$ 5.43 \mathrm{GGE}^{-1}$ ), because the ethanol yield of the non-enzymatic strategy is $29.3 \%$ higher, leading to significantly higher fuel production $\left(33.5 \times 10^{6}\right.$ vs. $25.9 \times 10^{6}$ GGE $\mathrm{yr}^{-1}$ ). Also, the MSP of ethanol for the non-enzymatic strategy is $14 \mathbb{\$}$ per GGE lower than that of the NREL process ( $\$ 5.13 \mathrm{GGE}^{-1}$ ) because of $14.4 \%$ lower average total annualized cost resulting from the absence of expensive enzymes, despite 5.6\% lower ethanol production. The electricity credit obtained in the non-enzymatic strategy is $\$ 0.06$ $\mathrm{GGE}^{-1}$, which is $1.1 \%$ of the overall cost of ethanol $\left(\$ 5.05 \mathrm{GGE}^{-1}\right)$ that is equal to the sum of MSP of ethanol and electricity credit.

Fig. 5 shows the contribution to the MSP by process section. The feedstock (corn stover) cost is the highest contributor $\left(\$ 1.73 \mathrm{GGE}^{-1}, 34.7 \%\right)$ while the two-stage reaction section is the second highest contributor ( $\left.\$ 1.15 \mathrm{GGE}^{-1}, 23.0 \%\right)$. The contribution of capital cost (83.5\%) to the reaction cost is significantly higher compared to those of material (4.3\%) and other operating costs (12.2\%).

\subsection{Sensitivity analysis}

We studied the sensitivities of the MSP with respect to key economic and process parameters (Fig. 6a). The variation in the selected parameters reflect the values reported recently by NREL (Humbird et al., 2011). The feedstock cost appears to be the dominant cost driver, while the overall sugars-to-ethanol molar yields have moderate impact. When feedstock cost was reduced from $\$ 83 /$ ton (base case scenario) to $\$ 60 /$ ton, the MSP decreased by $9.5 \%$. When the overall sugars-to-ethanol molar yields increased from $87 \%$ 
(base case scenario) to 91\%, the MSP decreased by 3.6\%. If both parameters are adjusted simultaneously, the MSP decreases by $13.1 \%$ to $\$ 4.33 \mathrm{GGE}^{-1}$ which is close to conventional fuel. Furthermore, recent studies suggest that the molar yield of sugars-toethanol can be as high as 96\%. Thus, using higher overall ethanol yield and reduced feedstock cost decreases the MSP of ethanol to $\$ 4.13 \mathrm{GGE}^{-1}$.

The potentially transformative characteristic of the proposed strategy is the use of a biomass-derived solvent (GVL) instead of expensive enzymes for the deconstruction of biomass to sugars. Nevertheless, based on the currently available experimental results, the overall solvent:biomass mass ratio in the reactor system is 14:1 which leads to: (1) large flow of GVL moving through the system, which in turn leads to increased capital investment; and (2) large energy requirements for the separation of GVL from sugars (extraction) and the separation of GVL from biomass residues (evaporation). Since this technology is at its infancy, however, it is reasonable to expect significant improvements (reductions) in the amount of GVL necessary to achieve effective biomass deconstruction. To assess the economic impact of such potential improvements, the impact of the solvent:biomass ratio to the MSP was studied (Fig. 6b). When the ratio was reduced from 14:1 to $10: 1$ (8:1), the MSP decreased by $10.0 \%(17.1 \%)$ to $\$ 4.49 \mathrm{GGE}^{-1}\left(\$ 4.13 \mathrm{GGE}^{-1}\right)$, mainly due to a $16.4 \%$ (27.5 \%) reduction in the reaction cost. Furthermore, the total energy (heating and electricity) requirements after heat integration decreased by $15.2 \%$ (34.1\%) to 74.9 MW (58.2 MW) which results in an increase in the electricity credit from $\$ 0.06 \mathrm{GGE}^{-1}$ to $\$ 0.16 \mathrm{GGE}^{-1}\left(\$ 0.27 \mathrm{GGE}^{-1}\right)$. This suggests that the solvent:biomass ratio is indeed a key parameter and that future research efforts should focus on the development of systems that utilize a smaller amount of solvent and/or alternative solvents. 


\section{Conclusions}

An integrated biofuels production strategy employing non-enzymatic sugar production using GVL as a solvent was developed. It was shown that the strategy has high biomass-toethanol yields, but requires the design of effective separation subsystems for the recycle of GVL as well as effective heat integration. The total heat and electricity requirements can be satisfied by burning lignin and biomass residues, while $67.1 \%$ of the energy content of cellulose and hemicellulose can be transformed into ethanol. A preliminary technoeconomic analysis suggests that this strategy could become an economically competitive alternative to current biofuels production approaches.

\section{Acknowledgements}

This work was funded by the DOE Great Lakes Bioenergy Research Center (DOE BER Office of Science DE-FC02-07ER64494). 


\section{References}

1. Alonso, D.M., Bond, J.Q., Dumesic, J.A. 2010. Catalytic conversion of biomass to biofuels. Green Chemistry 12, 1493-1513.

2. Anex, R.P., Aden, A., Kazi, F.K., Fortman, J., Swanson, R.M., Wright, M.M., Satrio, J.A., Brown, R.C., Daugaard, D.E., Platon, A., Kothandaraman, G., Hsu, D.D., Dutta, A. 2010. Techno-economic comparison of biomass-to-transportation fuels via pyrolysis, gasification, and biochemical pathways. Fuel 89, Supplement 1, S29-S35.

3. Bond, J.Q., Upadhye, A.A., Olcay, H., Tompsett, G.A., Jae, J., Xing, R., Alonso, D.M., Wang, D., Zhang, T., Kumar, R., Foster, A., Sen, S.M., Maravelias, C.T., Malina, R., Barrett, S.R.H., Lobo, R., Wyman, C.E., Dumesic, J.A., Huber, G.W. 2014. Production of renewable jet fuel range alkanes and commodity chemicals from integrated catalytic processing of biomass. Energy \& Environmental Science 7, 1500-1523.

4. Braden, D.J., Henao, C.A., Heltzel, J., Maravelias, C.T., Dumesic, J.A. 2011. Production of liquid hydrocarbon fuels by catalytic conversion of biomass-derived levulinic acid. Green Chemistry 13, 1755-1765.

5. Conde-Mejía, C., Jiménez-Gutiérrez, A., El-Halwagi, M.M. 2013. Assessment of Combinations between Pretreatment and Conversion Configurations for Bioethanol Production. ACS Sustainable Chemistry \& Engineering 1, 956-965.

6. Corma, A., de la Torre, O., Renz, M., Villandier, N. 2011. Production of High-Quality Diesel from Biomass Waste Products. Angew Chem Int Edit 50, 2375-2378.

7. Dale, B.E., Ong, R.G. 2014. Design, implementation, and evaluation of sustainable bioenergy production systems. Biofuel Bioprod Bior 8, 487-503.

8. Daoutidis, P., Marvin, W.A., Rangarajan, S., Torres, A.I. 2013. Engineering Biomass Conversion Processes: A Systems Perspective. Aiche J 59, 3-18.

9. Demirbas, A. 2007. Progress and recent trends in biofuels. Progress in Energy and Combustion Science 33, 1-18.

10. Floudas, C.A., Elia, J.A., Baliban, R.C. 2012. Hybrid and single feedstock energy processes for liquid transportation fuels: A critical review. Computers \& Chemical Engineering 41, 24-51.

11. Gnansounou, E., Dauriat, A. 2010. Techno-economic analysis of lignocellulosic ethanol: A review. Bioresource Technology 101, 4980-4991.

12. Han, J., Sen, S.M., Alonso, D.M., Dumesic, J.A., Maravelias, C.T. 2014. A strategy for the simultaneous catalytic conversion of hemicellulose and cellulose from lignocellulosic biomass to liquid transportation fuels. Green Chemistry 16, 653-661.

13. Holladay, J., Bozell, J., White, J., Johnson, D. 2007. Top value-added chemicals from biomass. Volume II-Results of Screening for Potential Candidates from Biorefinery Lignin, Report prepared by members of NREL, PNNL and University of Tennessee.

14. Huber, G.W., Iborra, S., Corma, A. 2006. Synthesis of Transportation Fuels from Biomass: Chemistry, Catalysts, and Engineering. Chemical Reviews 106, 4044-4098.

15. Humbird, D., Davis, R., Tao, L., Kinchin, C., Hsu, D., Aden, A., Schoen, P., Lukas, J., Olthof, B., Worley, M. 2011. Process Design and Economics for Biochemical Conversion of Lignocellulosic Biomass to Ethanol: Dilute-Acid Pretreatment and Enzymatic Hydrolysis of Corn Stover. National Renewable Energy Laboratory (NREL), Golden, CO.

16. Kádár, Z., Maltha, S.F., Szengyel, Z., Réczey, K., De Laat, W. 2007. Ethanol fermentation of various pretreated and hydrolyzed substrates at low initial $\mathrm{pH}$. Applied biochemistry and biotechnology 137, 847-858.

17. Kazi, F.K., Fortman, J.A., Anex, R.P., Hsu, D.D., Aden, A., Dutta, A., Kothandaraman, G. 2010. Techno-economic comparison of process technologies for biochemical ethanol production from corn stover. Fuel 89, Supplement 1, S20-S28. 
18. Lange, J.-P. 2007. Lignocellulose conversion: an introduction to chemistry, process and economics. Biofuels, Bioproducts and Biorefining 1, 39-48.

19. Lau, M.W., Dale, B.E. 2009. Cellulosic ethanol production from AFEX-treated corn stover using Saccharomyces cerevisiae 424A(LNH-ST). Proceedings of the National Academy of Sciences 106, 1368-1373.

20. Lee, Y., Iyer, P., Torget, R.W. 1999. Dilute-acid hydrolysis of lignocellulosic biomass. in: Recent Progress in Bioconversion of Lignocellulosics, Springer, pp. 93-115.

21. Lozowski, D. 2012. Chemical engineering plant cost index (CEPCI). Chem Eng 119, 84.

22. Luterbacher, J.S., Rand, J.M., Alonso, D.M., Han, J., Youngquist, J.T., Maravelias, C.T., Pfleger, B.F., Dumesic, J.A. 2014. Nonenzymatic Sugar Production from Biomass Using Biomass-Derived $\gamma$-Valerolactone. Science 343, 277-280.

23. Martín, M., Grossmann, I.E. 2011. Process Optimization of FT-Diesel Production from Lignocellulosic Switchgrass. Industrial \& Engineering Chemistry Research 50, 1348513499.

24. Olsson, L., Hahn-Hägerdal, B. 1996. Fermentation of lignocellulosic hydrolysates for ethanol production. Enzyme and Microbial Technology 18, 312-331.

25. Pham, T.N., Shi, D.C., Resasco, D.E. 2014. Evaluating strategies for catalytic upgrading of pyrolysis oil in liquid phase. Appl Catal B-Environ 145, 10-23.

26. Pham, V., El-Halwagi, M. 2012. Process synthesis and optimization of biorefinery configurations. Aiche J 58, 1212-1221.

27. Sammons Jr, N.E., Yuan, W., Eden, M.R., Aksoy, B., Cullinan, H.T. 2008. Optimal biorefinery product allocation by combining process and economic modeling. Chemical Engineering Research and Design 86, 800-808.

28. Schnepf, R., Yacobucci, B.D. 2010. Renewable Fuel Standard (RFS): overview and issues. Congressional Research Service: Washington, DC.

29. Sen, S.M., Henao, C.A., Braden, D.J., Dumesic, J.A., Maravelias, C.T. 2012. Catalytic conversion of lignocellulosic biomass to fuels: Process development and technoeconomic evaluation. Chem. Eng. Sci. 67, 57-67.

30. Swanson, R.M., Platon, A., Satrio, J.A., Brown, R.C. 2010. Techno-economic analysis of biomass-to-liquids production based on gasification. Fuel 89, S2-S10.

31. Tao, L., Aden, A., Elander, R.T., Pallapolu, V.R., Lee, Y.Y., Garlock, R.J., Balan, V., Dale, B.E., Kim, Y., Mosier, N.S., Ladisch, M.R., Falls, M., Holtzapple, M.T., Sierra, R., Shi, J., Ebrik, M.A., Redmond, T., Yang, B., Wyman, C.E., Hames, B., Thomas, S., Warner, R.E. 2011. Process and technoeconomic analysis of leading pretreatment technologies for lignocellulosic ethanol production using switchgrass. Bioresource Technology 102, 1110511114.

32. Uppugundla, N., Sousa, L.D., Chundawat, S.P.S., Yu, X.R., Simmons, B., Singh, S., Gao, X.D., Kumar, R., Wyman, C.E., Dale, B.E., Balan, V. 2014. A comparative study of ethanol production using dilute acid, ionic liquid and AFEX (TM) pretreated corn stover. Biotechnol Biofuels 7.

33. Wright, M.M., Brown, R.C. 2007. Comparative economics of biorefineries based on the biochemical and thermochemical platforms. Biofuel Bioprod Bior 1, 49-56.

34. Wright, M.M., Daugaard, D.E., Satrio, J.A., Brown, R.C. 2010. Techno-economic analysis of biomass fast pyrolysis to transportation fuels. Fuel 89, S11-S19.

35. Zhong, C., Lau, M.W., Balan, V., Dale, B.E., Yuan, Y.J. 2009. Optimization of enzymatic hydrolysis and ethanol fermentation from AFEX-treated rice straw. Appl Microbiol Biot 84, 667-676. 


\section{Figure Captions}

Fig. 1 Process flowsheet for two-stage reaction section.

Fig. 2 Process flowsheet for the integrated conversion strategy.

Fig. 3 Energy requirements (MW) of each process section before and after heat integration.

Fig. 4 Energy flow diagram after heat integration. Five major heat loads recovered by heat exchange are also shown. Black numbers refer to MW, blue (bold and italic) numbers refer to \% units, and purple (underlined) numbers denote temperatures (K).

Fig. 5. Cost contribution per process section $\left(\$ G G E^{-1}\right)$. The total cost $\left(\$ 5.05 G_{G E}{ }^{-1}\right)$ includes also utilities $\left(\right.$ capital $=\$ 0.08 \mathrm{GGE}^{-1}$, operating $\left.=\$ 0.01 \mathrm{GGE}^{-1}\right)$ and storage $\left(\right.$ capital $=\$ 0.03 \mathrm{GGE}^{-}$ , operating $\left.=\$ 0.01 \mathrm{GGE}^{-1}\right)$.

Fig. 6 (a) Impact of adjusting the key economic/process parameters to those of NREL (2011). (b) Impact of GVL:biomass ratio on the MSP of ethanol. 
Table 1 A summary of reaction yields for the conversion of hemicellulose and cellulose.

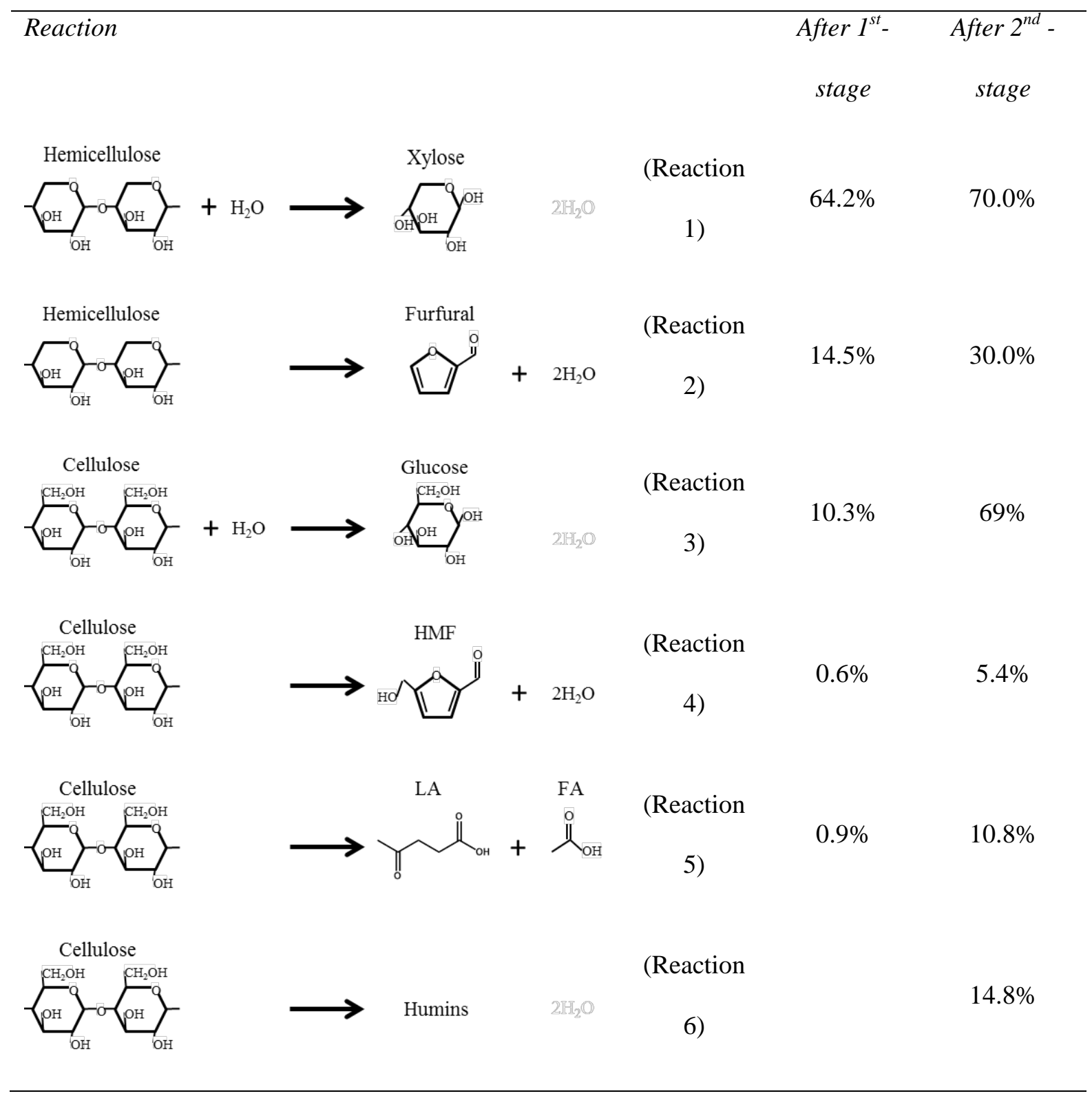


Table 2 A summary of reaction yields for the conversion of sugars into ethanol.

\begin{tabular}{|c|c|c|c|c|}
\hline Reaction & & & & Yields(\%) \\
\hline $2 \overbrace{\mathrm{OH}}^{\mathrm{Glucose}}$ & $\begin{array}{l}\text { Ethanol } \\
2 \widehat{\mathrm{OH}}\end{array}$ & $+2 \mathrm{CO}_{2}$ & $\begin{array}{c}\text { (Reaction } \\
7)\end{array}$ & $87.0 \%$ \\
\hline $3 \widehat{\mathrm{OH}}^{2 \mathrm{OH}}$ & $\begin{array}{l}\text { Ethanol } \\
5 \widehat{\mathrm{OH}}\end{array}$ & $+\quad{ }_{2}^{5 \mathrm{CO}_{2}}$ & $\begin{array}{c}\text { (Reaction } \\
8)\end{array}$ & $87.0 \%$ \\
\hline
\end{tabular}


Table 3 Capital and operating costs for the non-enzymatic ethanol production strategy, the catalytic alkenes production strategy and the enzymatic ethanol production strategy

\begin{tabular}{|c|c|c|c|c|c|c|c|}
\hline \multirow[t]{2}{*}{ Capital cost (MM\$) } & & \multicolumn{6}{|c|}{ Operating cost (MM\$/year) } \\
\hline & $\begin{array}{l}\text { Non- } \\
\text { enzymatic } \\
\text { ethanol } \\
\text { production }\end{array}$ & $\begin{array}{l}\text { Catalytic } \\
\text { alkenes } \\
\text { producti } \\
\text { on (Han } \\
\text { et al., } \\
\text { 2014) }\end{array}$ & $\begin{array}{l}\text { enzymatic } \\
\text { ethanol } \\
\text { productio } \\
\text { n (Kazi et } \\
\text { al., 2010) }\end{array}$ & & $\begin{array}{l}\text { Nonenzymati } \\
\text { c ethanol } \\
\text { production }\end{array}$ & $\begin{array}{l}\text { Catalytic } \\
\text { alkenes } \\
\text { productio } \\
\text { n (Han et } \\
\text { al., 2014) }\end{array}$ & $\begin{array}{l}\text { enzymatic } \\
\text { ethanol } \\
\text { productio } \\
\text { n (Kazi et } \\
\text { al., 2010) }\end{array}$ \\
\hline $\begin{array}{l}\text { Pretreatment/Biomass } \\
\text { conversion }\end{array}$ & 85.7 & 36.6 & 36.2 & Enzyme & & & 37.1 \\
\hline $\begin{array}{l}\text { Extraction/ } \mathrm{CO}_{2} \\
\text { separation }\end{array}$ & 42.8 & & & $\begin{array}{l}\mathrm{CO}_{2} \\
\text { makeup }\end{array}$ & 1.5 & & \\
\hline $\begin{array}{l}\text { Biochemical } \\
\text { conversions }\end{array}$ & 7.2 & & 21.8 & $\begin{array}{l}\text { Sulfuric } \\
\text { and makeup }\end{array}$ & 1.6 & 0.2 & 2.4 \\
\hline Catalytic conversions & 2.0 & 29.8 & & $\begin{array}{l}\text { Other raw } \\
\text { materials }\end{array}$ & 5.4 & 2.7 & 15.6 \\
\hline $\begin{array}{l}\text { Distillation/Solids } \\
\text { recovery }\end{array}$ & 15.9 & 17.1 & 26.1 & $\begin{array}{l}\text { Waste } \\
\text { disposal }\end{array}$ & 5.0 & 2.2 & 6.8 \\
\hline Feedstock handling & 10.9 & 10.9 & 10.9 & $\begin{array}{l}\text { Catalyst } \\
\text { regeneratio } \\
\mathrm{n}\end{array}$ & 0.3 & 3.5 & \\
\hline Wastewater treatment & 2.9 & 8.8 & 3.5 & $\begin{array}{l}\text { Utilities } \\
\text { usage }\end{array}$ & 0.2 & 1.2 & \\
\hline $\begin{array}{l}\text { Boiler/Turbogenerato } \\
\mathrm{r}\end{array}$ & 48.5 & 55.5 & 56.1 & Fixed costs & 12.1 & 10.1 & 9.9 \\
\hline Utilities & 6.9 & 8.7 & 6.3 & Feedstock & 57.9 & 57.9 & 57.9 \\
\hline Storage & 3.1 & 3.2 & 3.2 & & & & \\
\hline TOTAL & 225.8 & 170.5 & 164.1 & TOTAL & 83.9 & 77.7 & 129.7 \\
\hline
\end{tabular}


Table 4 Comparison of costs and revenues of the non-enzymatic ethanol production strategy with the catalytic alkenes production strategy and the enzymatic ethanol production strategy (\$ / GGE)

\begin{tabular}{|c|c|c|c|c|c|c|}
\hline & \multicolumn{2}{|c|}{$\begin{array}{l}\text { Non-enzymatic ethanol } \\
\text { production }\end{array}$} & \multicolumn{2}{|c|}{$\begin{array}{l}\text { Catalytic alkenes production } \\
\text { (Han et al., 2014) }\end{array}$} & \multicolumn{2}{|c|}{$\begin{array}{l}\text { enzymatic ethanol production } \\
\text { (Kazi et al., 2010) }\end{array}$} \\
\hline & Revenues & Costs & Revenues & Costs & Revenues & Costs \\
\hline Production & & 2.50 & & 3.00 & & 3.66 \\
\hline $\begin{array}{l}\text { Capital } \\
\text { depreciation }\end{array}$ & & 0.67 & & 0.66 & & 0.46 \\
\hline $\begin{array}{l}\text { Average } \\
\text { income tax }\end{array}$ & & 0.55 & & 0.56 & & 0.40 \\
\hline Average ROI & & 1.32 & & 1.30 & & 0.93 \\
\hline $\begin{array}{l}\text { Electricity } \\
\text { income }\end{array}$ & 0.06 & & 0.09 & & 0.33 & \\
\hline Fuel income & 4.99 & & 5.43 & & 5.13 & \\
\hline
\end{tabular}




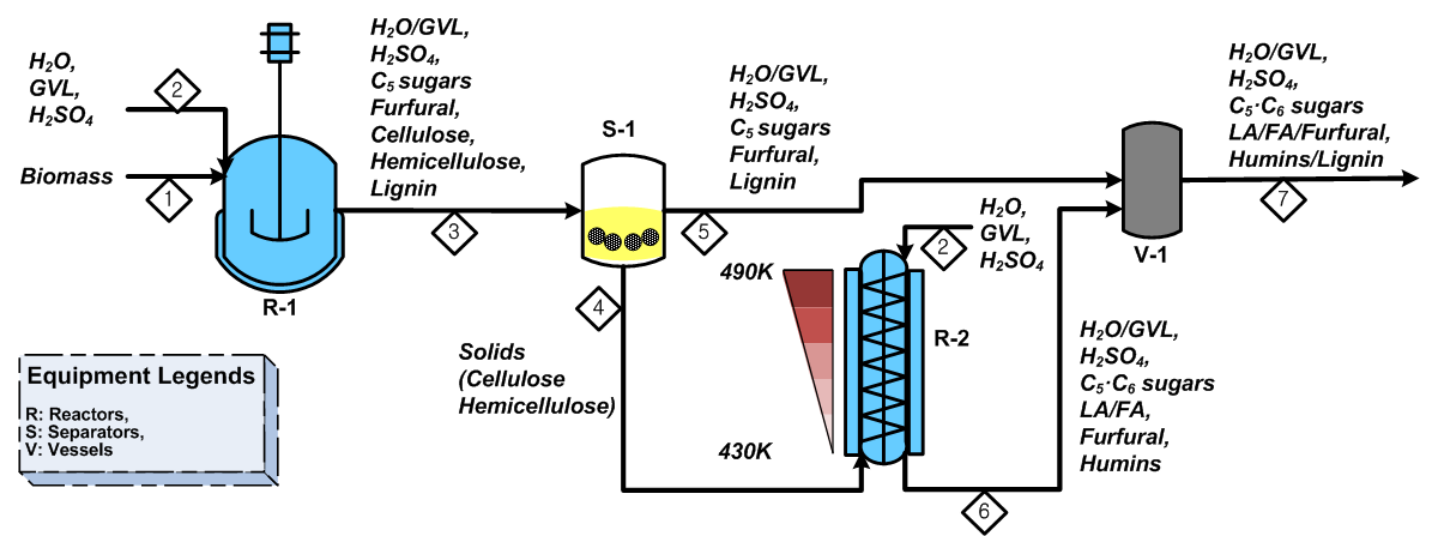

Fig. 1 Process flowsheet for two-stage reaction section. 


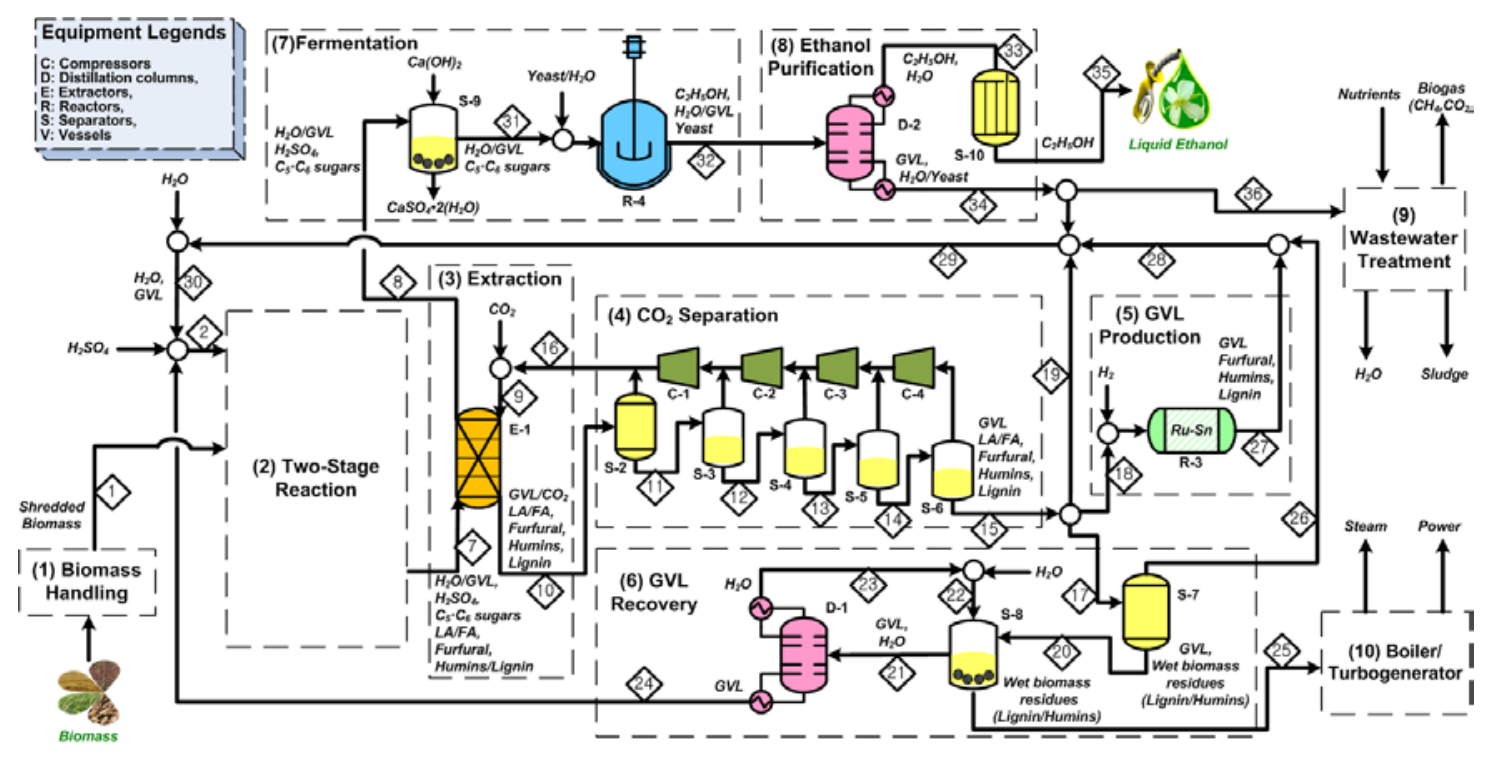

Fig. 2 Process flowsheet for the integrated conversion strategy. 


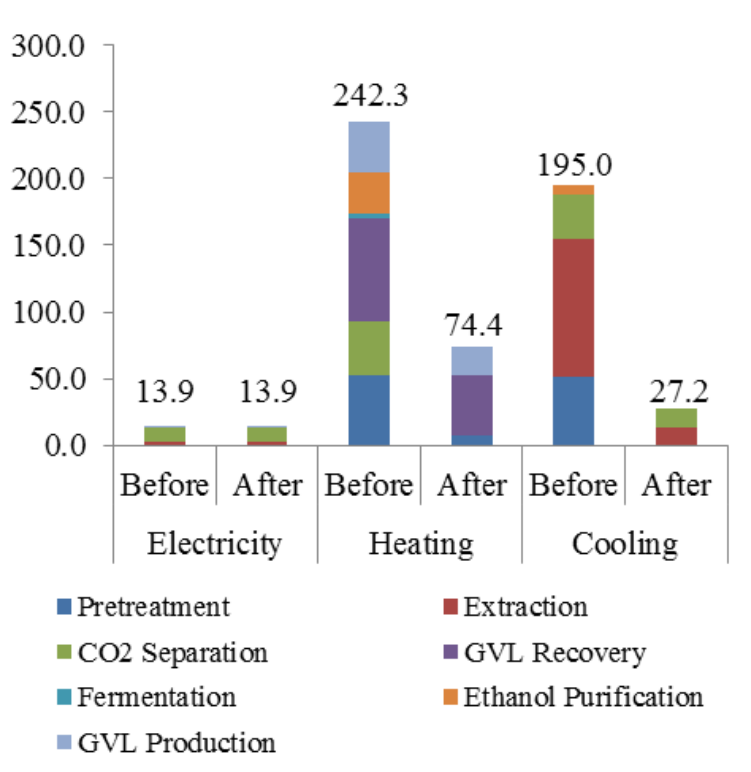

Fig. 3 Energy requirements (MW) of each process section before and after heat integration 


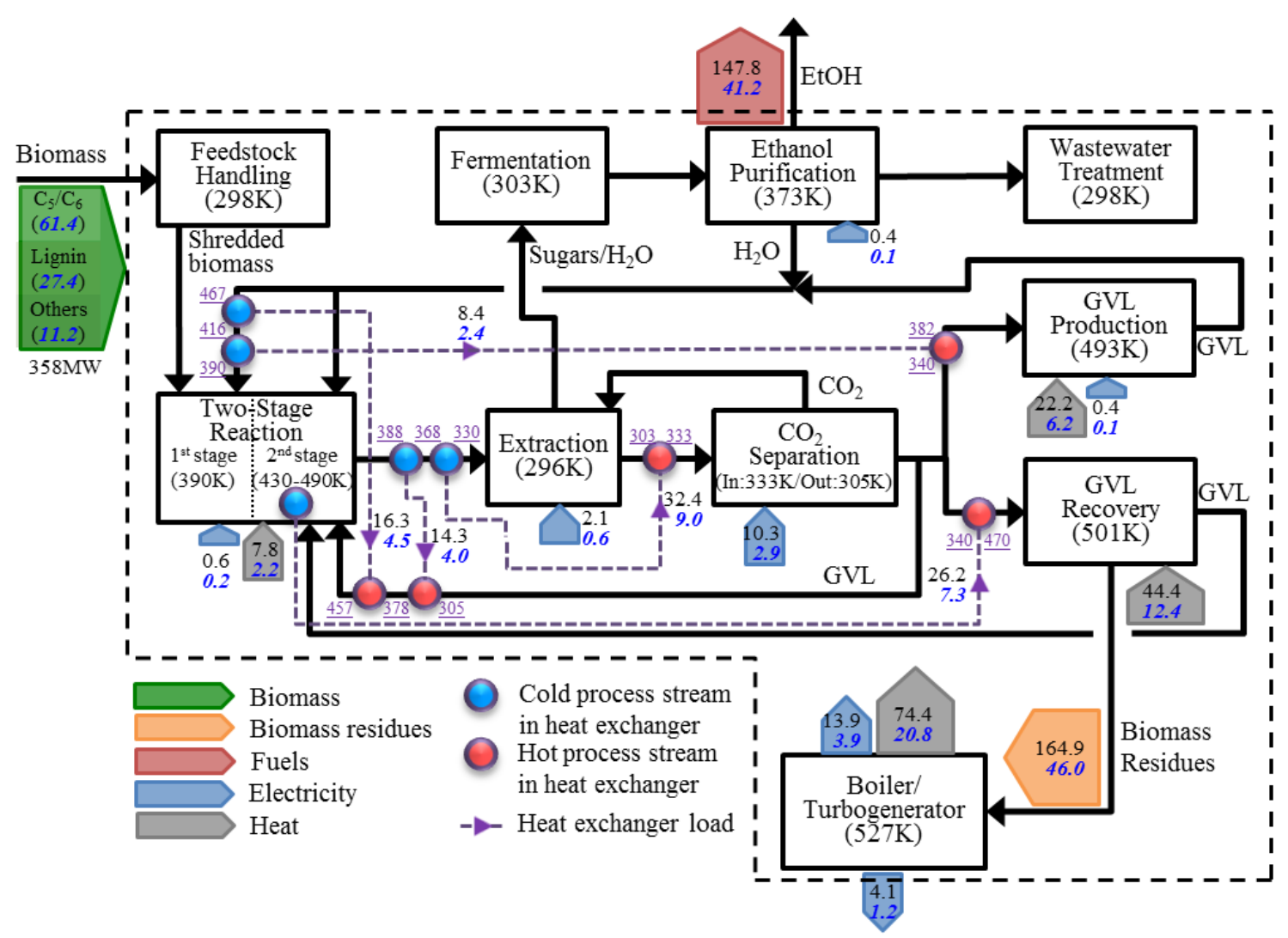

Fig. 4 Energy flow diagram after heat integration. Five major heat loads recovered by heat exchange are also shown. Black numbers refer to MW, blue (bold and italic) numbers refer to \% units, and purple (underlined) numbers denote temperatures (K). 


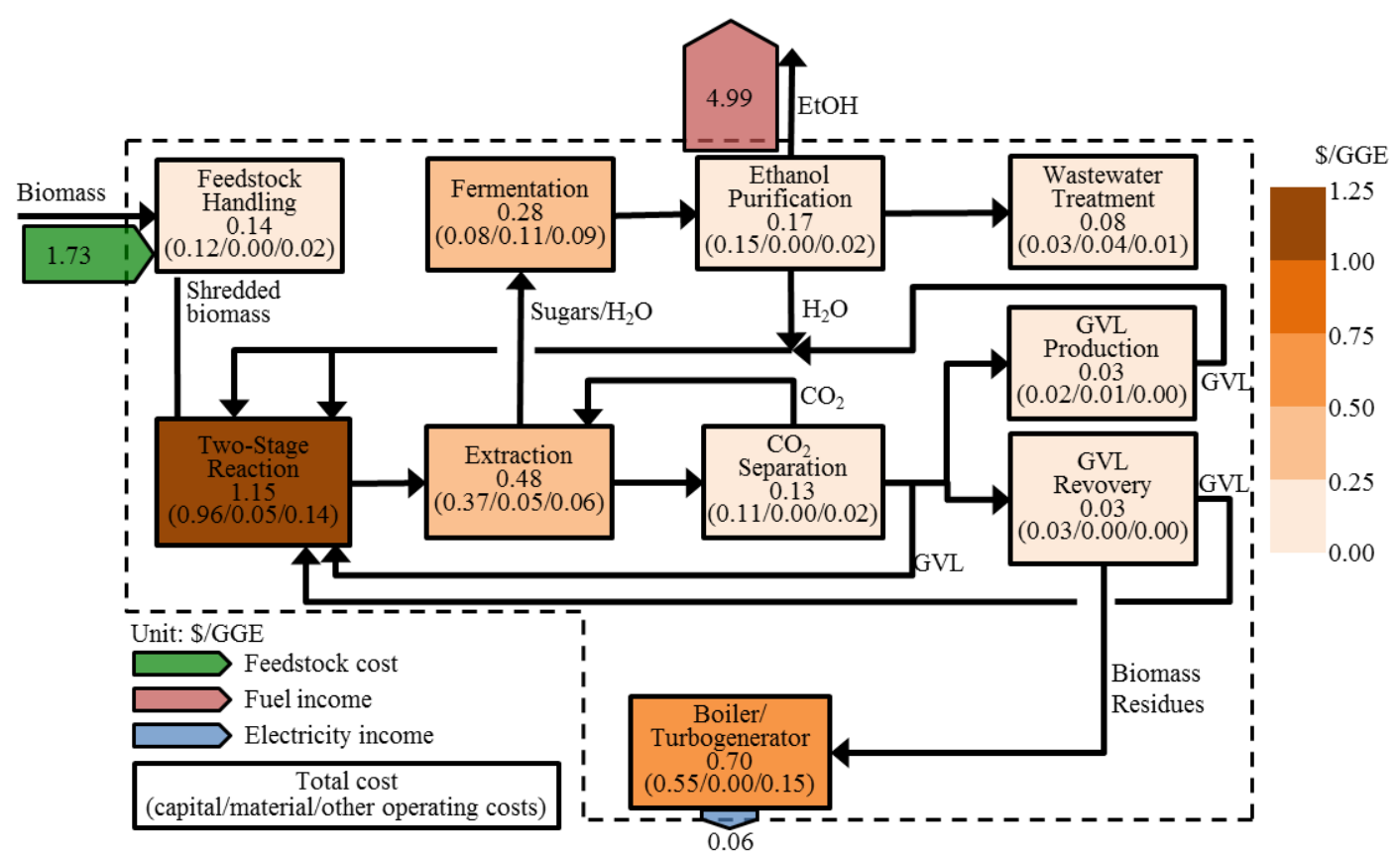

Fig. 5. Cost contribution per process section $\left(\$ G_{G E}^{-1}\right)$. The total cost $\left(\$ 5.05 G G E^{-1}\right)$ includes also utilities (capital $=\$ 0.08 \mathrm{GGE}^{-1}$, operating $=\$ 0.01 \mathrm{GGE}^{-1}$ ) and storage $\left(\right.$ capital $=\$ 0.03 \mathrm{GGE}^{-1}$, operating $=\$ 0.01$ $\left.\mathrm{GGE}^{-1}\right)$. 
(a)

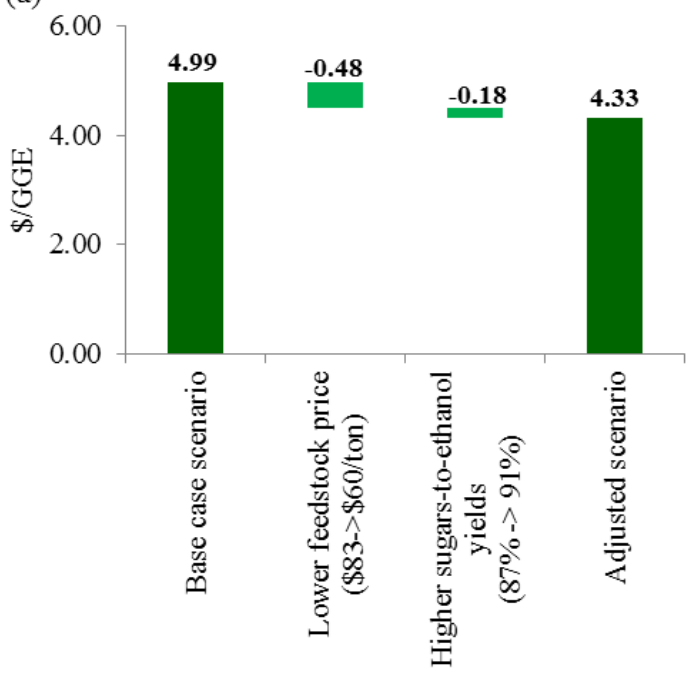

(b)

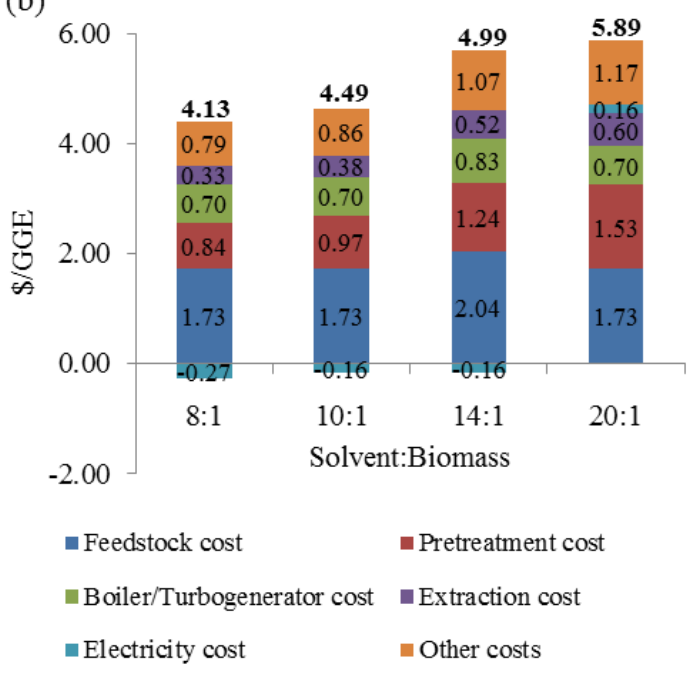

Fig. 6(a) Impact of adjusting the key economic/process parameters to those of NREL (2011). (b) Impact of GVL:biomass ratio on the MSP of ethanol. 


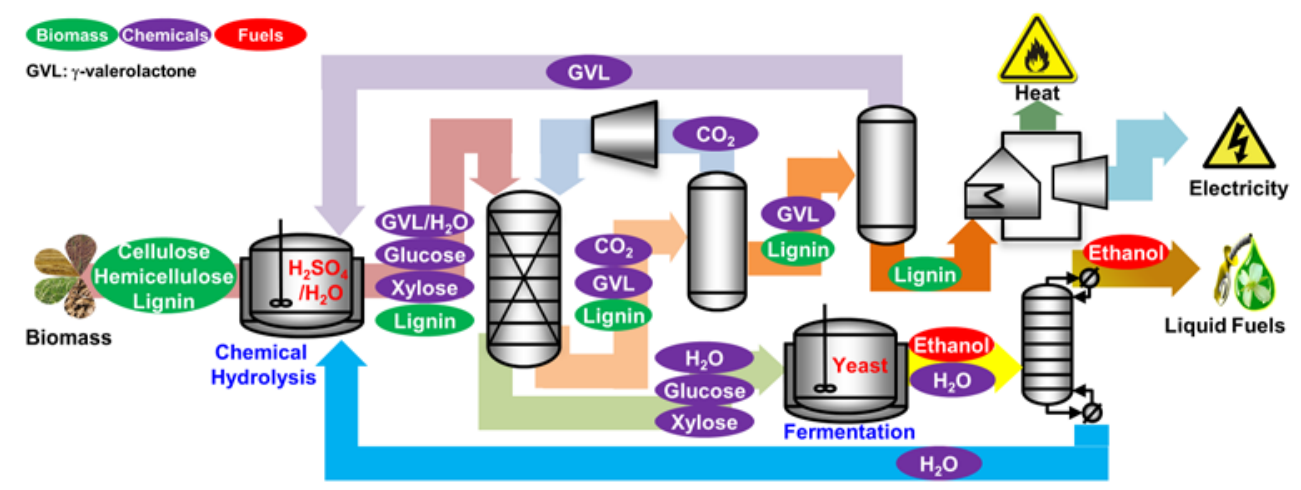

Graphical Abstract 